\title{
THE NON-SOCIALIST ORIGINS OF ENGLAND'S FIRST IMPORTANT SOCIALIST ORGANIZATION
}

England's first important socialist organization was the SocialDemocratic Federation. During the eighteen-eighties this organisation was in the forefront of the socialist movement. It came to present an extreme and dogmatic socialism. But it is curious to recall that in origin the organization was not socialist. Although it had a few socialist members, it had no socialist program. The leader of the S.D.F., the wealthy Cambridge University graduate, the formerly pro-Tory journalist, H. M. Hyndman, is always associated with the growth and development of this organization. Yet it has not been recognized that in the very early days of the S.D.F. there was no certainty that Hyndman would hold the reins. Our aim in this essay is twofold: I. to detail the non-socialist beginnings of the S.D.F. and 2. to indicate Hyndman's connection with the new organization. The story of the formation of the S.D.F. - at first called the Democratic Federation ${ }^{1}$ - has never been told in its entirety. ${ }^{2}$ We will relate what happened at the first meetings. We will show how Hyndman came to gain control and how the Member of Parliament from Newcastle, Joseph Cowen, who could have been the leader, was superseded.

1 The name was changed to the Social-Democratic Federation in 1884 .

${ }^{2}$ In the official history of the Social-Democratic Federation H. W. Lee writes, "What took place before the formal establishment of the Democratic Federation is not very clear." H. W. Lee and E. Archbold, Social-Democracy in Britain (London, 1935), p. 44. Lee then makes mistakes in his attempt to guess what happened. The account of the meetings given in J. Morrison Davidson, The Annals of Toil, pt. 4 (London, [1898?]), PP. $435-436$ is garbled; Davidson has confounded the happenings of two separate meetings into one. His evidence is untrustworthy although suggestive. In practically every history of the English socialist movement there is scant mention of the founding meetings, often derived from Hyndman's recollections, The Record of an Adventurous Life (London, I9II). The best attempt to reconstruct what occurred before the founding conference is made in Henry Pelling, The Origins of the Labour Party (London, 1954), pp. 16-18. We are indebted to Dr. Pelling's suggestions in this book. 
In the Spring of 188 I three preliminary meetings and then a founding conference were held. ${ }^{1}$ At these meetings the program for the Democratic Federation was shaped. The first meeting was called by Hyndman and H. A. M. Butler-Johnstone, a Tory M. P. from Canterbury. Workingmen and members of parliament who opposed coercion in Ireland were invited. ${ }^{2}$ Hyndman had discussed with Karl Marx the advisability of reviving the Chartist movement. Marx expressed sympathy, while at the same time questioning the wisdom of such a course. ${ }^{3}$ Hyndman's plan was to form a federation of "advanced clubs" around a radical program - a program similar to the Chartist program. He tells us of five old Chartists whom he attracted to the preliminary meetings. ${ }^{4}$

The first meeting took place on March 2, 1881 at the Rose Street Club, a club in Soho where foreign socialists congregated. J. Lord, a member of the English section of the Rose Street Club, ${ }^{5}$ presided. ${ }^{6}$ An active participant in the discussion was Edwin Dunn, also of the Rose Street Club. A few months later Dunn chaired a public meeting of the Socialist (Anarchist) International Congress held in London; ${ }^{7}$ then he denounced capital and government in every form. ${ }^{8}$ But from the Democratic Federation's formative meeting at the Rose Street Club there came no attack on capital. Dunn, speaking at this meeting, said that "in and around London there were about 80 political organizations, but their political power had been of little avail from want of unity." 9 The aim of a new organization would be simply to unite these Radical groups. The meeting adopted a provisional program of manhood suffrage, equal electoral districts, and payment of members of parliament. A committee was appointed to see the Radical M. P. Joseph Cowen who had indicated he would "join and assist" such an organization as was here projected. ${ }^{10}$

Three days later - March 5 - Cowen presided at the second formative meeting of the Democratic Federation. Delegates from a large number

1 No historian of the Social-Democratic Federation has noted that there were three key meetings before the founding conference.

${ }^{2}$ Letter from H. M. Hyndman to Karl Marx, February 28, $188 \mathrm{r}$, Marx Papers, International Institute of Social History, Amsterdam.

s Hyndman, op cit., p. 273.

4 James and Charles Murray, "Bill" Morgan, John Townsend, and Oliver, ibid., p. 246.

5 The club had English, French, and German sections.

The Radical, March 5, I88I, p. 3.

7 Daily Telegraph, July I9, I88I, p. 3; Pall Mall Gazette, July I9, I88I, p. 7.

8 Pall Mall Gazette, loc. cit.

The Echo, March 3, I88I, p. 3.

10 Ibid, and The Radical, March 5, 1881, p. 3. See also letter from Hyndman to Marx, op.cit., for Cowen's willingness to assist. 
of London clubs came to the Westminster Palace Hotel to attend. ${ }^{1}$ Cowen spoke in terms similar to those of Dunn: they met to consider the best means of uniting the workingmen's clubs "in a movement having for its object the promotion and settlement of the various pressing social and political questions of the day." 2 A motion was proposed by Butler-Johnstone favoring a central organization of the clubs. ${ }^{3}$

Speaking on the motion, Cowen "strongly condemned the caucus system, which made the present House of Commons the most slavish ever known. The caucuses all acted in support of the Government, no matter what the principle was at stake."4 Professor E. S. Beesly, the positivist, said "he would not support an organization, the aim of which was simply to promote Radicalism ${ }^{5}$ but let them have a definite object - 'Justice to Ireland' or 'Justice to the Transvaal' - and he should support it." Another positivist delegate to the conference, Henry Crompton, thought the new organization should be on the pattern of a labor league. ${ }^{7}$ Lloyd Jones, an old Owenite and Christian Socialist, argued that labor representation was not particularly important "as the present representatives of labour in Parliament had not shadowed forth any new political program." 8

After much discussion Butler-Johnstone's motion to endeavor to form a new party was passed unanimously. ${ }^{9} \mathrm{~A}$ subcommittee was then set up to draft a program. ${ }^{10}$ Cowen, Beesly, Hyndman, and ButlerJohnstone were among the members of this committee. ${ }^{11}$

1 Among the clubs represented were the Marylebone Radical Club, Land Nationalisation Society, London Society of Compositors, Tower Hamlets Radical Club, King's Cross Radical Club, Social Democratic Club, Lambeth Democratic Association, and Battersea Liberal Club. See Daily News, March 7, r88ז, p. 2.

2 Daily News, March 7, 188 I, p. 2.

3 Ibid.

4 Ibid. This speech goes to substantiate Dr. Pelling's thesis that the Democratic Federation may "be regarded as the product of a reaction against the Chamberlain caucuses." Pelling, op.cit., p. 18.

${ }^{5}$ Daily News, loc.cit. and Anon., John Williams and the Early History of the Social Democratic Federation (London, 1886), p. 3.

${ }^{6}$ Daily News, loc.cit.

7 Ibid.

8 The Echo, March 7, 1881, p. 2.

9 The Radical, March 12, I881, p. 2.

${ }^{10}$ See letter from Butler-Johnstone, Paris, to Karl Marx, March 7, I88I, Marx Papers, Int. Inst. Soc. Hist., Amsterdam.

11 The Radical, March I 2, I881, p. 2. The other members of the committee were Lord, Dunn, Devenish, and Garcia. In The Radical the list reads "... Butler, Johnstone..." We presume this is a typographical error for Butler-Johnstone. There was, however, a Butler, an Anarchist, who became a member of the Democratic Federation Executive Committee. Perhaps he is referred to on the committee list? 
Either in the week before the third meeting or at the third meeting we suggest that some friction occurred among the founders. We speculate that Hyndman asserted himself and revealed his aim to be the leader of the movement; that the Radicals objected, since they were distrustful of Hyndman owing to his newness to the movement and perhaps his overbearing personality. ${ }^{1}$ In any case neither The Radical nor The Echo, both Radical newspapers, reported this meeting; both had reported the first two meetings. ${ }^{2}$

The third meeting, and perhaps the most important of these early meetings, was held on March 19, 1881 - once again at the Westminster Palace Hotel. ${ }^{3}$ Significantly this was the first meeting of the Democratic Federation at which Hyndman presided. Up to now he had been in the background. Cowen did not attend. The delegates discussed the proposed Radical program. Dr. G. B. Clark, a Radical who was to become a member of parliament in $188 \mathrm{~s}$, urged that adult suffrage be substituted for manhood suffrage. Finlayson of the Manchester Democratic League suggested that land nationalization be added to the program; there is no record of this proposal having been mentioned at the earlier meetings. ${ }^{4}$ Land nationalization is frequently cited as the only plank of "a socialist nature" in the entire program of the Democratic Federation. ${ }^{5}$ It is of passing interest that this was not Hyndman's contribution.

At this meeting Professor Beesly for the first time opposed the setting up of a new party on the grounds that the time was not ripe. ${ }^{6}$

1 Hyndman throughout his period of leadership was continually alienating those whom he should have attracted. William Clarke wrote of Hyndman: "Many think him a humbug and a 'bad lot'." Letter to Henry Demarest Lloyd, October 22, I 884, Henry Demarest Lloyd Papers, State Historical Society of Wisconsin, Madison, Wisc. John Burns wrote of "Hyndman's egoism and jealousy." Diary entry for October 2, 1888, Burns Papers, Add. Ms. 463 Io, British Museum.

${ }^{2}$ We find this hard to attribute to oversight. The Radical knew that the meeting was occurring because in its issue of March 19, p. I, it announced the meeting. And later, The Echo's extraordinarily scant coverage of the June 8th founding conference which was widely reported elsewhere would indicate a lack of Radical interest.

${ }^{8}$ The only complete report that we have found of this meeting is in the Daily News, March 2r, I88I, p. 3. Our comments on this meeting are based on this report qualified by reference to other sources.

4 It may, however, have been mentioned at an earlier meeting and just not reported, for the Land Nationalisation Society sent a delegate to the second meeting.

${ }^{5}$ See, for instance, M. Beer, History of British Socialism (2 vols., London, 1921), II, p. 247.

${ }^{6}$ Beesly's opposition to setting up a new party, reported in the Daily News, is confirmed by J. Morrison Davidson, op. cit., p. 435 , although Davidson confuses the meeting at which Beesly made this statement. It is likewise noted in John Williams and the Early History of the S.D.F., p. 3. Beesly is often mistakenly referred to as a founder of the S.D.F. (See for instance Labour Annual, 1897, p. 222), wherein in actuality he only participated in the founding meetings. 
But Beesly had no success in halting the plans, and a General Conference to adopt a program for the Democratic Federation was scheduled for the Wednesday of Whit week.

This founding conference was held at Memorial Hall, Farringdon Street, on June 8, i 881. Less than two decades later here would be the scene of the founding meeting of the Labour Representation Committee. Now, however, Hyndman was again in the chair. He announced that Cowen would have attended were it not for his obligation to be at the Stephenson demonstration in Newcastle. ${ }^{1}$ Among the celebrities there were J. L. Finigan, Irish M.P., and Sir John Bennett, businessman and common councillor. ${ }^{2}$ Miss Helen Taylor, the step-daughter of J. S. Mill, took an active part in the discussion, as did the Irish M.P., Justin McCarthy. Present also were a few old Chartists, a number of Radicals, and some Socialists. The founders' topics ranged from a consideration of Irish legislative independence to an abortive debate on the abolition of the hereditary monarchy.

On legislative independence for Ireland there was unanimity. ${ }^{3}$ Tyler, a delegate from Nottingham, had but to move its inclusion into the platform; A. J. Winks, for a short period to be Secretary of the Democratic Federation, to second Tyler's motion; and Justin McCarthy to speak with fervor for the cause; and the delegates were convinced.4 Rev. Harold Rylett, a member of the executive committee of the Land League, then invited two delegates of the new organization to be guests of the Land League on a visit to Ireland. The extended invitation, the pro-Irish spirit of the discussion, and the unanimity are important because they anticipated the orientation of most of the Democratic Federation's activities in its early years around events in Ireland.

Another harbinger of what was to come lay in the delegates' acceptance of nationalization of the land. An observer records that this plank was endorsed "with much ardour." Yet, he writes, "no one knew what the phrase meant, though several eloquent speeches were made about it. One cautious gentleman asked for a definition from the chairman or anyone else, but he was promptly ruled out of order, and no reply vouchsafed."

\footnotetext{
${ }^{1}$ Reynolds's Newspaper, June I 2, I 881, p. 2.

2 St. James's Gazette, June 9, 1881, p. 7; The Times, June 9, 1881, p. 6; and The Echo June 9,1881, p. 3 .

${ }^{3}$ Daily News, June 9, r88I, p. 2.

4 Reynolds's Newspaper, loc. cit. Identification of Tyler's locality appears in Daily Telegraph, June 9, $188 \mathrm{I}$, p. 5 .

5 Unsigned leader by J. Morrison Davidson, The New Party, in: Weekly Dispatch, June 12, I 881, p. 9. Morrison Davidson identifies this leader as his own in his The Annals of Toil, pt. 4 , p. 435 .
} 
There was considerably more controversy over the issue of adult versus manhood suffrage, with Hyndman apparently favoring the latter. ${ }^{1}$ On the other hand, Herbert Burrows, a Radical - the son of a Chartist, Methodist preacher - thought adult suffrage preferable, ${ }^{2}$ and Miss Helen Taylor enthusiastically agreed. ${ }^{3}$ So did the conferees who voted that all adults should have the right to participate in elections. The delegates also decided that the House of Lords was unnecessary and ought to be abolished. Now Peter O'Leary rose, declaring the hereditary monarchy too should go. This republican sentiment - shared by others in the room - was too much for Hyndman, who haughtily demurred: "rather than assent to such disloyalty he would rather vacate the chair." J J. Morrison Davidson, a Radical journalist, and Andreas Scheu, an Austrian Socialist, were so dismayed by this attitude that "we shook the dust from off our feet and left the hall."5 Eventually those gathered adopted a program which urged adult suffrage, triennial parliaments, equal electoral districts, payment of members, abolition of the House of Lords, bribery at elections to be made a felony, nationalization of the land, and legislative independence for Ireland. ${ }^{6}$

Hyndman distributed among those present his book, England for All, containing many of these points. Three planks, however, accepted at the meeting were not in his volume: land nationalisation (Hyndman had advocated extensive "land reform"); abolition of the House of Lords (Hyndman would have preferred to reform the upper chamber by sweeping away the hereditary principle); and legislative independence for Ireland (Hyndman had not included this, although he wrote with sympathy on the Irish plight). ${ }^{7}$ Yet all the basic political reforms that Hyndman had endorsed were accepted, though some in modified form. ${ }^{8}$ In a few ways Hyndman's book went beyond the platform of the new party. It was far more concerned with social

\footnotetext{
1 Hyndman, England for All (London, Gilbert \& Rivington, June, I 88 I), p. 93.

${ }^{2}$ Reynolds's Newspaper, loc. cit.

${ }^{2}$ Forty-two years later Andreas Scheu in his memoirs singled out Miss Helen Taylor's speech on this subject for mention. A. Scheu, Umsturzkeime - Dritter Teil: Auf Freiem Boden (Vienna, 1923), pp. 46-47.

4 So he was teported as saying by Davidson, The New Party, loc.cit.

${ }^{5}$ Davidson, The Annals of Toil, pt. 4, p. 435. This story without names is confirmed in Hyndman, Record of an Adventurous Life, p. 250.

B See Pall Mall Gazette, June 9, I 88I, p. 8 for listing of all points adopted.

7 Hyndman, England for All, June, 1881 edition, pp. 30, 96, and $112-130$.

${ }^{8}$ Hyndman had advocated Equal Electoral Districts, Payment of Members, and Bribery at elections to be made a felony. But he urged manhood rather than adult suffrage and triennial rather than annual parliaments. Ibid., pp. 93 and 91.
} 
reform. ${ }^{1}$ Hyndman also suggested that "Railways... like the control of mines, factories, and workshops must be placed under the State."2 These views prepared the way for Hyndman's future position.

But of the socialist ideas that Hyndman had, he either lacked the power or the desire to urge them upon the founders of the Democratic Federation. We suggest that Hyndman had not yet the authority to direct the new organization along socialist lines, and that moreover he was still in large part satisfied with the Radical program adopted. There is no evidence to indicate that Hyndman tried to put socialist views into the program formulated at the founding conference. The ideas may have been in England for All, but they were not introduced into the discussion at Memorial Hall.

Thus on June $8,188 \mathrm{I}$ the Democratic Federation was finally launched. In no sense was it a socialist organization. It did not advocate collective ownership and control of the means of production. With the exception of land nationalization, all the changes it proposed were political rather than social. No newspaper, in reporting the advent of the new party, mentioned "socialism." Neither in fact did Hyndman, who likened the Federation's program to that of the Magna Charta Association ${ }^{3}$ - a Radical group. Similarly, the proposals of the Democratic Federation gained the approval of the members of the Magna Charta Association.

Yet although the latter agreed with the platform of the new organization, they did not care for Hyndman. A member of the executive council of the Magna Charta Association announced "they wanted an English as well as an Irish Parnell," and he proposed Joseph Cowen "for the vacant post of "leader of the English people"." 4

Cowen has been described as England's "leading Democrat" of this period. ${ }^{5}$ He might have become chairman of the Democratic Federation at this point, for he was the obvious choice. In I 876 he had been suggested as a chief of a projected Radical party of the extreme left. ${ }^{6}$ Then he had declined the responsibility, and no such party was formed. Now the offer was again before him. We have seen that Cowen presided at the second formative meeting of the Democratic Federation. It is not strictly true, as reported by Morrison Davidson, that Cowen then ceased to take active interest in the movement ${ }^{7}$ he did chair a meeting

1 Ibid., p. Iro.

2 Ibid., p. 107.

${ }^{3}$ Pall Mall Gazette, September 8, x88, p. 4.

4 Ibid.

${ }^{5}$ He is described in these terms in Davidson, Annals of Toil, pt. 4, p. 435.

- William Duncan, Life of Joseph Cowen (London, I 904), p. gr.

7 Davidson, Annals of Toil, pt. 4, P. 435. 
of the Federation held in June, 1882 , to protest against coercion in Ireland.1 But in general Cowen did not associate himself with the new organization. Neither of his biographers has anything to say about his activity in relation to the Democratic Federation. ${ }^{2}$ Cowen had the chance to head the new group, yet just as he had backed down in 1876 , so in $188 \mathrm{I}$ he did not take the initiative.

Instead, Hyndman became the leader. In September, $188 \mathrm{I}$, two new editions of Hyndman's England for All appeared, one a "cheap edition... at a price which will bring it within reach of all."3 Both were now subtitled "The Text-Book of Democracy" and their contents were modified to conform with the decisions reached at the Democratic Federation's founding conference.4 "Nationalisation of the land" and "legislative independence for Ireland" were now included in the new editions. ${ }^{\circ}$ By October 2, $188 \mathrm{I}$, we find Hyndman writing to Miss Helen Taylor: "For my part I have thrown in my lot with the Federation finally." "Hyndman, undeterred by the lack of Radical support evidenced by the attitude of The Echo and The Radical, ${ }^{7}$ unimpeded by the criticisms of him in the Weekly Dispatch, ${ }^{8}$ a paper edited by the old Radical H. R. Fox Bourne, undaunted by the opposition to his personal leadership of such Radical organizations as the Magna Charta Association, proceeded to devote himself fulltime to managing the Democratic Federation.

Hyndman had in 1880 opposed Home Rule for Ireland; by $188 \mathrm{I}$ he had changed his mind entirely and was on the executive of the Land League. In I 880 Hyndman had read Marx's Capital and had been impressed. But in $\mathrm{I} 88 \mathrm{I}$ he was not totally won over to socialism. Early in that year he could speak of the socialist "fanatics" in Germany. ${ }^{9}$ In England for All he would incorporate two chapters on labor and capital that were taken directly from Marx. ${ }^{10}$ Yet in the first

1 Pelling, op.cit., p. 22.

${ }^{2}$ See Duncan, op. cit., and E.R. Jones, The Life and Speeches of Joseph Cowen, M.P. (London, 1885).

3 The cheap edition was published by E. W. Allen in September, 188 I. Gilbert \& Rivington also put out a second edition in September. The pagination of the two is the same. We are much indebted to Mr. F. Kool, Editorial Secretary of this Review, for pointing out the differences between the June edition of England for All and the September editions.

5 England for All (September editions), pp. zon and 130.

- See letter from H.M. Hyndman, London, to Miss Helen Taylor, October 2, $188 \mathrm{r}$, in Mill-Taylor Papers, British Library of Political and Economic Science. - Our italics.

7 See p. 5 above.

i.e. in [Davidson], "The New Party," op. cit.

- H. M. Hyndman, Dawn of a Revolutionary Epoch in: The Nineteenth Century, IX (January $188 \mathrm{I}$ ), p. 5 .

10 Chapters II and III. 
edition of England for All, June, I88I, he would still write of "the demon of Socialism," identifying socialism with anarchism. ${ }^{1}$ In September, I88I, however, the phrase "demon of Socialism" was omitted from the revised editions of this book. The changes in England for All indicate Hyndman's developing position. As I 88 I drew to a close and 1882 began, Hyndman moved more and more toward a revolutionary socialist point of view. By the end of $\mathrm{x} 882$, Hyndman was a complete and thorough-going revolutionary socialist.

At the same time as Hyndman's ideas moved in this direction, he took the Democratic Federation with him, that is the organization if not all its members (for the group splintered first over its vigorously pro-Irish stand ${ }^{2}$ and then over the socialist policy ${ }^{3}$ ). It was Hyndman who gave the Democratic Federation his untiring support, and it was he who guided it from the Radical program of the June 8th Memorial Hall meeting - a program that had his almost complete sympathy to the socialist program of only two years later - a program that had his entire endorsement.

1 England for All (June, I88I edition), p. 86.

${ }^{2}$ See letter from H. M. Hyndman, London, to Miss Helen Taylor, October 2, $188 \mathrm{I}$, in Mill-Taylor Papers.

${ }^{3}$ Lee and Archbold, op.cit., p. 53. 